Review

\title{
Cell Supermarket: Adipose Tissue as a Source of Stem Cells
}

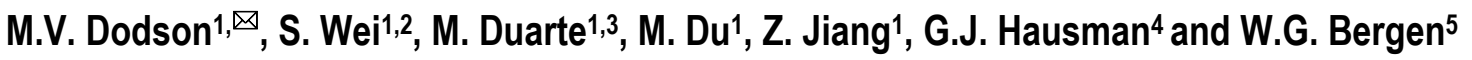 \\ 1. Department of Animal Sciences, Washington State University, Pullman, WA 99164, USA \\ 2. College of Animal Science and Technology, Northwest A\&F University, Yangling, Shaanxi Province 712100, China \\ 3. Department of Animal Science, Federal University of Viçosa, Viçosa, MG 36570-000, Brazil \\ 4. United States Department of Agriculture, Agriculture Research Services, Athens, GA 30605, USA \\ 5. Program in Cellular and Molecular Biosciences, Department of Animal Sciences, Auburn University, Auburn, AL 36849, USA
}

$\triangle$ Corresponding author: Dr. M.V. Dodson, Department of Animal Sciences, Washington State University, Pullman, WA 99164; Tel: +1 509-335-9644; FAX: +1 509335 1082; E-mail: dodson@wsu.edu

(C) Ivyspring International Publisher. This is an open-access article distributed under the terms of the Creative Commons License (http://creativecommons.org/ licenses/by-nc-nd/3.0/). Reproduction is permitted for personal, noncommercial use, provided that the article is in whole, unmodified, and properly cited.

Published: 2013.11.20

\begin{abstract}
Adipose tissue is derived from numerous sources, and in recent years this tissue has been shown to provide numerous cells from what seemingly was a population of homogeneous adipocytes. Considering the types of cells that adipose tissue-derived cells may form, these cells may be useful in a variety of clinical and scientific applications. The focus of this paper is to reflect on this area of research and to provide a list of potential (future) research areas.
\end{abstract}

Key words: adipocytes, stromal vascular cells, mature adipocytes, stem cells, transdifferentiation

\section{Introduction}

The focus of this issue of the Journal of Genomics is on adipocyte biology. It might be easy to simply think about adipocytes as those "pesky" cells that conspire against us to fill with fat as we age to make us look differently. Upon a closer look at adipocyte cell lineage origins, physiology, bodily repository locations (depots) and also at the adipocyte's ability to perform a diverse set of metabolic functions other than just simply to "pad" our bodies (especially in the wrong places), it might be surprising to learn that adipocytes have profound impacts on a variety of major bodily systems beyond just lipid storage [1-3]. Consequently, a focus of this issue of the Journal of Genomics was to shed light on adipocytes, bring adipocyte biology into the molecular level and to identify gaps in contemporary understanding of various aspects of adipocyte biology--especially with respect to adipogenesis (genomics, transcriptomics and metabolomics) [4]. By doing so, we hope to generate enthusiasm in this research area and to (perhaps) recruit more people into the arena of adipocytes. One area that was presented in numerous papers of this issue as segmented informative bits [5-8] was the potential for cells found in adipose depots to become other cells, so the "stem cell(s)" of adipose tissue is/are briefly discussed by this paper.

\section{Adipocytes are derived from multiple types of cells}

Mesenchymal (and perhaps other germ layer-origin) stem cells [9-13], adipofibroblasts [14, 15], stromal vascular cells [6], preadipocytes $[6,16,17]$, satellite cells $[10,11]$ and (even though considered post-mitotic) [18] mature adipocytes [19-39] all provide cells that can assimilate lipid and display lipid metabolism [17, 40, 41]. Cells such as bone-derived cells not originally displaying the adipocyte phenotype might be induced to become an adipocyte $[18,34$, $42,43]$ and numerous maladies such as lipotrophic muscular atrophy (a good model is Japanese Black cattle) [44] and steatosis [2,17] have been described whereby original tissue was replaced by adipose-like 
cells perhaps regulated via intercellular signals/cross talk between muscle and adipose tissue/cells [45]. This results in cells losing their original function while maintaining original tissue size and structure [46].

Embryonic development. In a similar manner to the development of skeletal muscle in utero, it seems likely that embryonic adipogenesis may involve numerous populations of stem cells [13]. Since the proportions of embryonic/fetal stem cells for the production of adipocytes may be altered [13], it would be of interest to determine if the same relative proportional changes observed during in utero development are maintained throughout postnatal growth. Enhanced understanding here might point to means for augmenting specific populations of "desired" adipocyte-like cells to the exclusion of others $[1,13,41]$.

Postnatal development and growth. The choice of a particular type of adipocyte-like cell to identify putative markers of cell physiology transitions from proliferative cells into cells that are conducting lipid metabolism needs to be carefully scrutinized and weighed $[10,40]$. Indeed, sorting out the subpopulations of cells within adipose depots will allow more a discrete definition of such pathways, while allowing a determination of how "flexible" the population might be for other applications [17, 41, 47]. Inclusion of different sizes of mature adipocytes [48, 49], or their dedifferentiated progeny cells [47] in many of these types of studies will help define whether differentiation really exists, as traditionally defined, or whether we will need to reassess adipogenesis from all sides $[12,29,40]$. In addition there may be species dependent functional characteristics that could impact such studies. For example adipocytes in avian adipose tissues do not exhibit de novo fatty acid synthesis while de novo fatty acid synthesis may occur at high rates in mammalian adipose depots [50].

\section{Cells from adipose tissue may form other types of cells}

The work of Prunet-Marcassus et al. (rodent cells, [51]) and Planat-Bernard et al. (human cells, [52]) first suggested that adipose tissue contains a number of progenitor cells of several cell phenotypes. Most remarkably, these authors demonstrated that adipose tissue cells can give rise to adipocytes, osteoblasts, myoblasts, endothelial cells, and hematopoietic cells among other phenotypes [51]. This has raised numerous speculative biological questions. For example, is the cellularity of cells that form what appear to be lipid-filled adipocytes, as well as the mature adipocytes that might lose lipid and become proliferative-competent progeny cells, phenotypically "flexible?" Also, are isolated adipose-derived cells capable of forming many (other) types of cells?

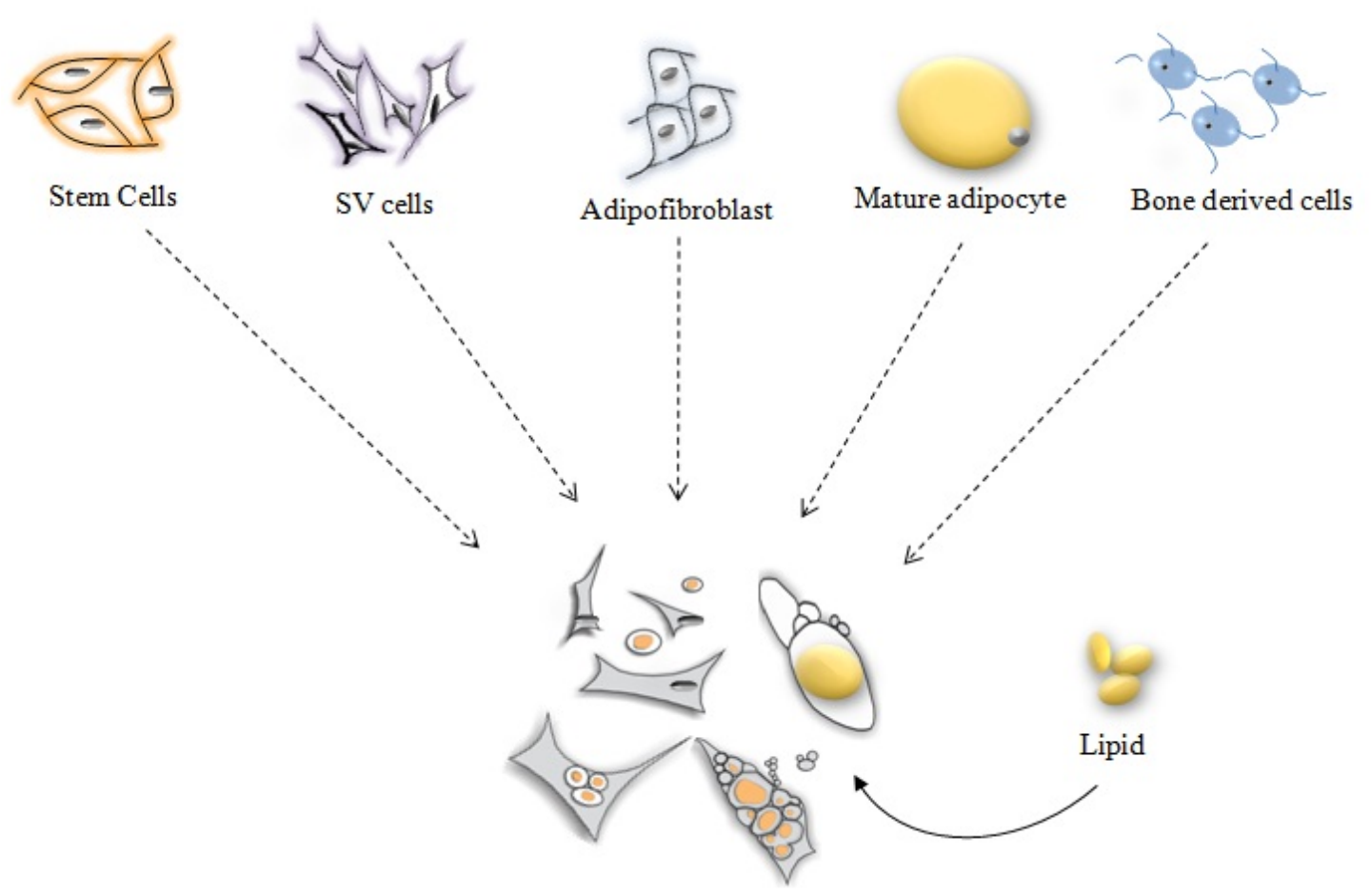

Figure I. Ability of different types of cells to form adipocytes. 


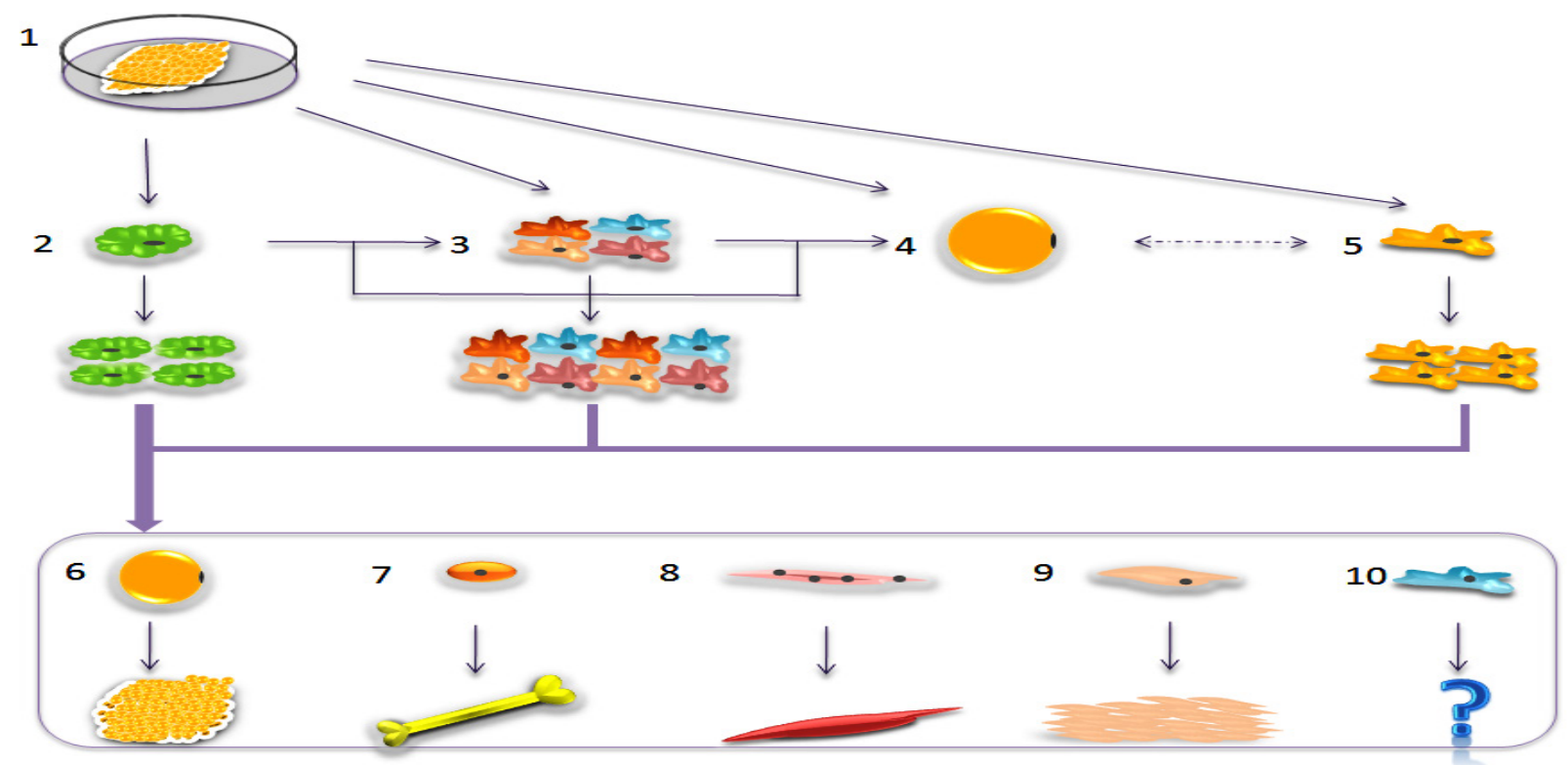

Figure 2. Postnatal adipogenesis and mutilineage potential of adipose tissue. In postnatal adipose tissue (I), mesodermal cells (2), stromal vascular cells (3), mature adipocytes (4) and progeny cells (5) are all involved in the adipogenesis process. Stromal vascular cells (3) are a mixed population, which contain preadipocytes, fibroblasts, endothelial cells, blood cells, macrophages or mesenchymal cells, etc. Traditional adipogenesis refers that, under signal regulation, stromal vascular cells or mesodermal cells could differentiate into round mature adipocytes (4). However, recent studies have showed that mature adipocytes could dedifferentiate into progeny cells (5) and these cells would redifferentiate into mature adipocytes under the proper situation. Mesodermal cells, stromal vascular cells and progeny cells are somewhat similar. Under certain conditions, these cells all have the ability to proliferate and could differentiate into many types of cells [such as adipocytes (6), osteoblasts (7), myoblasts (8), endothelial cells (9) and other types of cells (10)], eventually developing into fat, bone, muscle, endothelial, and other possible tissues.

Numerous studies have already provided evidence to address these questions, and adipocyte-derived cells from numerous sources appear capable of forming many other types of cells $[5,6,10-12$, $17,26,30,33,41,48,53-59]$. Moreover, in general it has been estimated that adipose tissue may provide numerically higher amounts of stem cells [60] for use in a variety of applications than any other stem cell source of the body [26, 47, 61, 62]. Also, the phenotype of adipose tissue-derived cell populations distinguishes adipose tissue depots from one another [51]. Collectively, cells derived from adipocyte populations may serve as a smorgasbord of progeny cells for biotechnology, tissue engineering, surgery, direct tissue repair (regenerative medicine), and thus serve as a cell supermarket [10, 12, 26, 37, 46, 53, 59-61, 63-67].

The choice of species for the most promising model to study certain aspects of adipogenesis and trans/dedifferentiation by individual workers is likely highly dependent on the animal resources of an institution. The availability of multiple species, in particular farm animals, would offer potentially a highly diverse/smorgasbord sources of cells. While such species (in addition to rodent and cell lines) are generally available at institutions with agricultural and veterinary colleges, such an approach may not be realistic for mainstream biomedical research centers. Here the principal cell resources and infrastructure may only accommodate rodent tissues, human tissues and cell lines. It would also appear that for commercial application, adipose tissue related cells from farm species would for the foreseeable future be available only as primary cells. In additions strategies and means would have to be developed for rapid distribution of harvested cells. Unfortunately unless there are overriding experimental model advantages for use of farm animal cells, the majority of workers in this field would continue to use rodent tissues, cell lines and available human adipose sources. Most likely if the majority of the work alluded to here would be done with rodents, then most of potential funding then would also be focused on these species. This then will place the institutions with extensive animal resources, including farm animals at a strategic disad- 
vantage to pursue this line of research from a comparative perspective.

\section{Immediate studies for the future}

1. The quantitative rate and extent (success) of cells derived from adipose depots to become transformed into other types of cells must be examined more closely. Not only is it important to determine if the cells can transdifferentiate, but whether there exist populations of these cells, whose proportions might be increased/decreased with lifestyle choices such as type of diet, amount of energy intake and level of exercise. In this respect, identification of the regulatory mechanism(s) involved in transdifferentiation is essential for understanding the cell physiology involved [26].

2. Are some adipocyte subpopulations more capable of serving different and useful roles? For example, research data are presently not available to predict what type of transdifferentiated adipocyte-like cells (and regulators) would be most beneficial to aid bone repair in a clinical setting versus a different set of cells and regulators which would be more advantageous to applications such as cosmetic surgery.

3. Future studies dealing strictly with cells derived from adipose tissues to be used in clinical settings need to consider variables such as: a) species and location of adipose depots from which such cells are to be derived, b) a clear delineation of representatives of all populations of potential stem cells that may be isolated (if possible) from given adipose depots, c) characterization of transdifferentiation potentials (endogenous or artificially induced) of harvested cells and d) establish whether heterogeneous cells arising originally from adipose depots may be reprogrammed into lipid-assimilating adipocyte-like cells

4. Considerable number of studies with human adipose tissue stromal/stem cell clearly demonstrated the nature and function of adipose tissue stro$\mathrm{mal} /$ stem cell progenitors (ADSC) of vascular entities like endothelial, perivascular and smooth muscle cells involved in angiogenesis and vasculogenesis. A novel vascular stem cell (VSC) theory proposes that ADSC are a mixed population of VSC with differential potential proportional to the angiogenic potential of the vasculature [68]. The differential potential of VSC can range considerably in a continuous as opposed to a discrete fashion and can include vascular smooth cells, endothelial cells and adipocytes [68]. ADSC are likely VSC at various stages of differentiation toward becoming smooth muscle and endothelial cells. At earlier stages of differentiation VSC can also differentiate in situ into host tissue-specific cell types such as adipocytes in their native tissue. Finally, depending on its differentiation potential at the time of isolation from the host tissue, an individual VSC may be induced to differentiate into additional cell types such as osteoblasts and chondrocytes. Therefore, ADSC may exist in adipose tissue as a mixed population of VSC as opposed to strictly as adipocyte stem cells. These emerging realities of cellular heterogeneity (pluripotent vs. committed cells for example), differentiation and trans/de-differentiation potential need further investigation.

\section{Summary}

The general characteristics of stem cell development to committed and finally differentiated cells have been described. Presently we are focusing on the potential of adipose tissues as a source of stem and other recommitted cells for further study and future clinical applications. Unfortunately the extent of our understanding of stem cell biology is still too limited to envision how a rich source of such cells (as adipose tissue) may be utilized in therapeutic programs in future clinical settings.

\section{Conflict of Interest}

The authors have declared that no conflict of interest exists.

\section{References}

1. Dodson MV, Mir PS, Hausman GJ, Guan LL, Du M, Jiang Z, Fernyhough ME, Bergen WG. Obesity, metabolic syndrome and adipocytes. J Lipids. 2011; 2011:721686

2. Dodson MV, Hausman GJ. Metabolic syndromes: Resolving a malady that involves numerous tissues, cells, regulators and regulatory pathways. J Metabol Syndro. 2011; 1: 1.

3. Majka SM, Barak Y, Klemm DJ. Concise review: Adipocyte origins: Weighing the possibilities. Stem Cells. 2011; 29: 1034-1040.

4. Basu U, Guan LL, Taniguchi M, Zhao Y, Dodson MV. Application of 'omics" Technologies on improvement of meat quality. In: Haugen S, Meijer S, ed. Nutritional biochemistry: Genomics, metabolomics and food supply. New York: Nova Science Publishers; 2009: 165-194.

5. Dodson MV, Jiang Z, Du M, Hausman GJ. Adipogenesis: It is not just lipid that comprises adipose tissue. J Genomics. 2013; 1: $1-4$.

6. Hausman GJ, Dodson MV. Stromal vascular cells and adipogenesis: Cells within adipose depots regulate adipogenesis. J Genomics 2013, 1: 56-66.

7. Wei S, Duarte M, Zan L, Du M, Jiang Z, Guan LL, Chen J, Hausman GJ, Dodson MV. Cellular and molecular implications of mature adipocyte dedifferentiation. J Genomics. 2013; 1: 5-12.

8. Xu Y, Zhu MJ, Dodson MV, Du M. Developmental programming of fetal skeletal muscle and adipose tissue development. J Genomics. 2013; 1: 29-38.

9. Billon N, Monteiro MC, Dani C. Developmental origin of adipocytes: New insights into a pending question. Biol Cell. 2008; 100: 563-575. 
10. Dodson MV, Du M, Velleman SG, Rhoads RP, McFarland DC, Fernyhough ME, Jiang Z, Hausman GJ. Skeletal muscle stem cells from animals II: Manipulation of skeletal muscle stem cells to effect a leaner body composition. Int J Biol Sci. submitted.

11. Dodson, MV, Hausman GJ, Guan LL, Du M, Rasmussen TP, Poulos SP, Mir P, Bergen WG, Fernyhough ME, McFarland DC, Rhoads RP, Soret B, Reecy JM, Velleman SG, Jiang Z. Skeletal muscle stem cells from animals I. Basic cell biology. Int J Biol Sci. 2010; 6: 465-474.

12. Du M, Dodson MV. Advanced techniques to enhance marbling in meat. Control of Meat Quality (Joo S, ed). 2011;: 105-115.

13. Du M, Tong J, Zhao J, Underwood KR, Zhu M, Ford SP, Nathanielsz PW. Fetal programming of skeletal muscle development in ruminant animals. J Anim Sci. 2010; 88: E51-E60.

14. Vierck JL, McNamara JP, Dodson MV. Proliferation and differentiation of progeny of ovine unilocular fat cells (adipofibroblasts). In Vitro Cell Dev Biol Anim. 1996; 32: 564-572.

15. Vierck JL, McNamara JP, Dodson MV. Two alternative procedures to isolate adipofibroblasts from sheep skeletal muscle. Meth Cell Sci. 1996; 18: 309-314.

16. Hausman GJ, Campion DR, Martin RJ. Search for the adipocyte precursor cell and factors that promote its differentiation. J Lipid Res. 1980; 21: 657-670.

17. Hausman GJ, Dodson MV, Ajuwon K, Azain M, Barnes K, Guan LL, Jiang Z, Poulos SP, Sainz RD, Smith S, Spurlock M, Novakofski J, Fernyhough ME, Bergen WG. Board invited re-view: The biology and regulation of preadipocytes and adipocytes in meat animals. J Anim Sci. 2009; 87: 1218-1246.

18. Park KW, Halperin DS, Tontonoz P. Before they were fat: Adipocyte progenitors. Cell Metab. 2008; 8: 454-457.

19. Adebonojo FO. Studies on human adipose cells in culture: relation of cell size and cell multiplication to donor age. Yale J Biol Med. 1975; 48: 9-16.

20. Adebonojo FO. Monolayer cultures of disaggregated human adipocytes. In Vitro. 1975; 11: 50-54.

21. Chen J, Guridi M, Fernyhough ME, Jiang Z, Guan LL, Hausman GJ, Dodson MV. Initial differences in lipid processing leading to pig- and beef-derived mature adipocyte dedifferentiation. Basic Appl Myol. 2009; 19: 243-246.

22. Chen J, Guridi M, Fernyhough ME, Jiang Z, Guan L, Hausman GJ, Dodson MV. Clonal Mature Adipocyte Production of Proliferative-competent Daughter Cells Requires Lipid Export Prior to Cell Division. Int J Stem Cells. 2009; 2: 76-79.

23. Chen J, Dodson MV, Jiang Z. Cellular and molecular comparison of redifferentiation of intramuscular- and visceral-adipocyte derived progeny cells. Int J Biol Sci. 2010; 6: 80-88.

24. Dodson MV, Hausman GJ, Guan LL, Du M, Jiang Z. Potential impact of mature adipocyte dedifferentiation in terms of cell numbers. Int J Stem Cells. 2011; 4: 76-78.

25. Dodson MV, Fernyhough ME, Vierck JL, Hausman GJ. Adipocytes may not be a terminally differentiated cell type: Implications for animal production. Anim Sci. 2005; 80:239-240.

26. Fernyhough ME, Hausman GJ, Guan LL, Okine E, Moore SS, Dodson MV. Mature adipocytes may be a source of stem cells for tissue engineering. Biochem Biophys Res Commun. 2008; 368: 455-457.

27. Fernyhough ME, Helterline DI, Vierck JL, Hausman GJ, Hill RA, Dodson MV. Dedifferentiation of mature adipocytes to form adipofibroblasts: More than a possibility. Adipocytes. 2005; 1: 17-24.

28. Fernyhough ME, Bucci L, Hausman GJ, Antonio J, Vierck JL, Dodson MV. Gaining a Solid Grip on Adipogenesis. Tissue Cell. 2005; 37: 335-338

29. Fernyhough ME, Vierck JL, Hausman GJ, Mir PS, Okine EK, Dodson MV. Primary adipocyte culture: adipocyte purification methods may lead to a new understanding of adipose tissue growth and development. Cytotechnology. 2004; 46: 163-172.
30. Matsumoto T, Kano K, Kondo D, Fukuda N, Iribe $Y$, Tanaka N, Matsubara Y, Sakuma T, Satomi A, Otaki M, Ryu J, Mugishima $\mathrm{H}$. Mature adipocyte-derived dedifferentiated fat cells exhibit multilineage potential. J Cell Physiol. 2008; 215: 210-222.

31. Nobusue H, Endo T, Kano K. Establishment of a preadipocyte cell line derived from mature adipocytes of GFP transgenic mice and formation of adipose tissue. Cell Tissue Res. 2008; 332: 435-446.

32. Ono H, Oki Y, Bono H, Kano K. Gene expression profiling in multipotent DFAT cells derived from mature adipocytes. Biochem Biophys Res Commun. 2011; 407: 562-567.

33. Shen J, Sugawara A, Yamashita J, Ogura H, Sato S. Dedifferentiatiated fat cells: and alternative source of adult multipotent cells from the adipose tissues. Int J Oral Sci. 2011; 3: 117-124.

34. Shigematsu M, Watanabe $H$, Sugihara $H$. Proliferation and differentiation of unilocular fat cells in the bone marrow. Cell Struct Funct. 1999; 24: 89-100.

35. Sugihara H, Yonemitsu N, Miyabara S, Toda S. Proliferation of unilocular fat cells in the primary culture. J Lipid Res. 1987; 28: 1038-1045.

36. Sugihara H, Funatsumaru S, Yonemitsu N, Miyabara S, Toda S, Hikichi Y. A simple culture method of fat cells from mature fat tissue fragments. J Lipid Res. 1989; 30: 1987-1995.

37. Tholpady SS, Aojanepong C, Llull R, Jeong JH, Mason AC, Futrell JW, Ogle RC, Katz AJ. The cellular plasticity of human adipocytes. Ann Plast Surg. 2005; 54: 651-666.

38. Yagi K, Kondo D, Okazaki Y, Kano K. A novel preadipocyte cell line established from mouse adult mature adipocytes. Biochem Biophys Res Commun. 2004; 321: 967-974.

39. Zhang HH, Kumar S, Barnett AH, Eggo MC. Ceiling culture of mature human adipocytes: use in studies of adipocyte functions. J Endocrinol. 2000; 164: 119-228.

40. Poulos SP, Dodson MV, Hausman GJ. Cell line models for differentiation: preadipocytes and adipocytes. Exp Biol Med. 2010; 235: 1185-1193.

41. Dodson, MV, Hausman GJ, Guan LL, Du M, Rasmussen TP, Poulos SP, Mir P, Bergen WG, Fernyhough ME, McFarland DC, Rhoads RP, Soret B, Reecy JM, Velleman SG,Jiang Z. Lipid metabolism, adipocyte depot physiology and utilization of meat animals as experimental models for metabolic research. Int J Biol Sci. 2010; 6: 682-690.

42. Park, SR, Oreffo ROC, Triffitt JT. Interconversion potential of cloned human marrow adipocytes in vitro. Bone. 1999; 24: 549-554.

43. Zeng L, Rahrmann E, Hu Q, Lund T, Sandquist L, Felten M, O'Brien TD, Zhang J, Verfaillie C. Multipotent adult progenitor cells from swine bone marrow. Stem Cells. 2006; 24: 2355-2366.

44. Ohsaki H, Sawa T, Sasazaki S, Kano K, Taniguchi M, Mukai F, Mannen H. Steroyl-CoA desaturase mRNA expression during bovine adipocyte differentiation in primary culture derived from Japanese Black and Holstein cattle. Biochem Physiol A Mol Integr Physiol. 2007; 148: 629-634.

45. Kokta T, Dodson MV, Gertler A, Hill RA. Intercellular signaling between adipose tissue and muscle tissue. Domest Anim Endocrinol. 2004; 27: 303-331.

46. Monlux WS, Monlux AW. Atlas of Meat Inspection Pathology; USDA Agriculture Handbook No.367. US:USDA. 1972: 153-155.

47. Dodson MV, Fernyhough M. Mature adipocytes: Are there still novel things that we can learn from them? Tissue Cell. 2008; 40: 307-308.

48. Cianzio DS, Topel DG, Whitehurst GB, Beitz DC, Self HL. Adipose tissue growth and cellularity: Changes in bovine adipocyte size and number. J Anim Sci. 1985; 60: 970-976.

49. Whitehurst GB, Beitz DC, Cianzio D, Topel DG, Johnson DC. Examination of a lognormal distribution equation for describing distributions of diameters of bovine adipocytes. J Anim Sci. 1981; 53: 1236-1245. 
50. Bergen WG, Mersmann HJ. Comparative aspects of lipid metabolism: impact on contemporary research and use of animal models. J Nutr. 2005; 135: 2499-2502.

51. Prunet-Marcassus B, Cousin B, Caton D, André M, Pénicaud L, Casteilla L. From heterogeneity to plasticity in adipose tissues: site-specific differences. Exp Cell Res. 2006; 312: 727-736.

52. Planat-Benard V, Silvestre JS, Cousin B, André M, Nibbelink M, Tamarat R, Clergue M, Manneville C, Saillan-Barreau C, Duriez M, Tedgui A, Levy B, Pénicaud L, Casteilla L. Plasticity of human adipose lineage cells toward endothelial cells: physiological and therapeutic perspectives. Circulation. 2004; 109: 656-663.

53. Fraser JK, Wulur I, Alfonso Z, Hedrick MH. Fat tissue: An underappreciated source of stem cells for biotechnology. Trends Biotechnol. 2006; 24: 150-154.

54. Fernyhough ME, Hausman GJ, Dodson MV. Progeny from dedifferentiated adipocytes display protracted adipogenesis. Cells Tissues Organs. 2008; 188: 359-372.

55. Jumabay M, Zhang R, Yao Y, Goldhaber JI, Bostrom KI. Spontaneously beating cardiomyocytes derived from white mature adipocytes. Cardiovasc Res. 2010; 85: 17-27.

56. Justensen J, Pedersen SB, Stenderup K, Kassem M. Subcutaneous adipocytes can differentiate into bone-forming cells in vitro and in vivo. Tissue Eng. 2004; 10: 381-391.

57. Oki Y, Watanabe S, Endo T, Kano K. Mature adipocyte-derived dedifferentiated fat cells can trans-differentiate into osteoblasts in vitro and in vivo only by all-trans retinoic acid. Cell Struct Funct. 2008; 33: 211-222.

58. Taha MF, Hedayati V. Isolation, identification and multipotential differentiation of mouse adipose tissue-derived stem cells. Tissue Cell. 2010; 42: 211-216.

59. Nakagami H, Morishita R, Maeda K, Kikuchi Y, Ogihara T, Kaneda Y. Adipose tissue-derived stromal cells as novel option for regenerative cell therapy. J Atheroscler Thromb. 2005; 13: 77-81.

60. Schaffler A, Buchler C. Concise review: Adipose tissue-derived stromal cells--basic and clinical implications for novel cell-based therapies. Stem Cells. 2007; 25: 818-827.

61. Jeong JH. Adipose stem cells as clinically available and effective source of adult stem cell therapy. Int J Stem Cells. 2008; 1: 43-48.

62. Strem BM, Hicok KC, Zhu M, Wulur I, Alfonso Z, Schreiber RE, Fraser JK, Hedrick MH. Multipotent differentiation of adipose tissue-derived stem cells. Keio J Med. 2005; 54: 132-141.

63. Gimble JM, Katz AJ, Bunnell BA. Adipose-derived stem cells for regenerative medicine. Circ Res. 2008; 100: 1249-1260.

64. Helder MN, Knippenberg M, Klein-Nulend J, Wuisman PIJM. Stem cells from adipose tissue allow challenging new concepts for regenerativemedicine. Tissue Eng. 2007; 13: 1799-1808.

65. Locke M, Windsort J, Dunbar R. Human adipose-derived stem cells: Isolation, characterization and applications for surgery. Anz J Surg. 2009; 79: 235-244.

66. Mizuno H. Adipose-derived stem cells for tissue repair and regeneration: Ten years of research and a literature review. J Nihon Med Sch. 2009; 76: 56-66.

67. Tholpady SS, Ogle RC, Katz AJ. Adipose stem cells and solid organ transplantation. Curr Opin Organ Transplant. 2009; 14: 51-55.

68. Lin G, Garcia M, Ning H, Banie L, Guo Y, Lue TF, Lin C. Defining stem and progenitor cells within adipose tissue. Stem Cells Dev. 2008; 17: 1053-1063. 